\title{
室內坐業者快感域に於ける乾力タ冷却力並に 室內気流について
}

\author{
横浜医科大学衛生学教室（主任 萩原兼文教授）
}

山 賀 岑 朗

生体が温度的作用をうけるのは通常気温, 気湿, 気流 及び輻射熱の 4 因子の複合によるものと考兄られてい る。勿論暑さ寒さを標示する基本的の因子が気温にある ことには異存はないとしても, 生体が温度条件に対して 反応するのは単一の物理的条件の各々ではなく，これら の複合したものに対してである以上，これら因子の 1 ケ または 2 ケをるつて温度条件の生物学的単位とすること の不十分であることは既に知られているところである1

従つてこの生物学的単位をいかに定むべきか沉ついて 多くの研究者の苦心があり，その一つとして Hill の提 唱によるカタ寒暖計がある。即ちとれより導かれるカタ 冷却力をるつて人体の熱放散の状態を機械的に示そうと するものであつて，その着想は劃期的なるのであり，た とえカタ寒暖計は形が余りに小であるため人体からの放 熱の場合にくらべて比較的高率の放熱が起ること, 即ち カタ冷却力の数値をるつて人体の寒暑感を示すことには 多少無理のあることが指摘され，生物学的な意味の温度 条件測定器具としての価値の評価は低下されて来たとは い党な持全く捨てさり得ない洒値は残つているるのと 考穴ている。

筆者は昭和27年来 Air Conditioning を行つている東 京都心の 2 新築ビルの調查の機会を得, 快感にあると思 われる個所の乾力タ冷却力と室内気流を検討し，その数 値にいささか興味ある点を見出したのでその結果を報告 する。

\section{I 調 查 方 法}

昭和 27 年 5 月, 8 月及び昭和 28 年 1 月の 3 時期に, コ ンジットウェザーマスター式による Air Conditioningを 行つている 2 ビルの環境を調査(その実態関する詳細 は別に報告される)したが，この際暑熱の 8 月と寒冷の 1 月の測定中, 感覚温度が快感带 (夏 $64 \sim 79^{\circ} \mathrm{F}$, 冬60

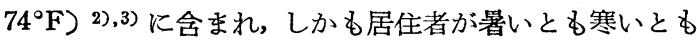
訴えていない個所を選び，乾カタ冷却力と室内気流を検 討した。測定には終始同一のカタ寒暖計を用い型の如く
計測した。な扔室内居住者は全て机上事務を執る坐業者 である。

\section{II 測 定 成 績}

暑熱時 ( 8 月) の調查海して快感域にあると目され る13ケ所，38回の测定成續は表 1 に示す通りである。こ の測定時の気候条件は, 戸外では乾球温度 $27.1 \sim 31.0^{\circ} \mathrm{C}$ 比湿 81 85\%に対し, 室内では乾梂温度 $23.4 \sim 26.4^{\circ} \mathrm{C}$ (平均 $25.6^{\circ} \mathrm{C}$ ), 比湿 $72 \sim 81 \%$ (平均 $77.1 \%$ ), 感覚 温度 $72.5 \sim 77.3^{\circ} \mathrm{F}$ (平均 $75.7^{\circ} \mathrm{F}$ ) であつた。

\section{表 18 月に於ける測定成繶}

\begin{tabular}{|c|c|c|c|c|c|c|c|c|c|}
\hline 榦及率 & & $\begin{array}{c}1.0 \\
3.9\end{array}$ & $\frac{4.0}{6.9}$ & $\begin{array}{c}7.0 \\
\tilde{9.9}\end{array}$ & $\stackrel{10.0}{\sim 2.9}$ & & $\begin{array}{c}16.0 \\
\widetilde{\sim} .9\end{array}$ & 19.0 & 計 \\
\hline 1 & $\sim$ & 0 & 0 & 0 & 0 & 0 & 0 & 0 & 0 \\
\hline 2 & $\sim$ & 2 & 0 & 0 & 0 & 0 & 0 & 0 & 2 \\
\hline 3 & $\sim$ & 0 & 9 & 13 & 6 & 2 & 1 & 0 & 31 \\
\hline 4 & $\sim$ & 0 & 0 & 1 & 0 & 1 & 2 & 1 & 5 \\
\hline 5 & $\sim$ & 0 & 0 & 0 & 0 & 0 & 0 & 0 & 0 \\
\hline 6 & $\sim$ & 0 & 0 & 0 & 0 & 0 & 0 & 0 & 0 \\
\hline & & 2 & 9 & 14 & 6 & 3 & 3 & 1 & 38 \\
\hline
\end{tabular}

表 1 にみる如く, 気流については 7.0 9.9cm/sec が 最子多く, 大多数が $4.0 \sim 12.9 \mathrm{~cm} / \mathrm{sec}$ の範囲にあるこ とが知られる。

一方乾カタ冷却力は 2.9 4.7 の範囲 (平均 3.5) に あり, しかもその大部分が 3 〜 代であつて，その 3 〜 代の平均は 3.4 であつた。

寒冷時 ( 1 月) の調査で快感域にあると認められる 12 ケ所, 20回の測定成績は表 2 に示す通りであり，この測 定時に於ける気候条件は, 戸外では乾球温度 $9.0 \sim 12.0^{\circ}$ $\mathrm{C}$, 比湿80 83\%であり, 室内では乾球温度 $21.0 \sim 24.8^{2}$ $\mathrm{C}\left(\right.$ 平均 $22.7^{\circ} \mathrm{C}$ )，比湿65７9\% (平些72.9\%)，感覚 温度 $68.8 \sim 73.5^{\circ} \mathrm{F}$ (平均70.7 $\mathrm{F}$ ) であつた。 
[198]

\section{表 21 月に於ける測定成䋨}

\begin{tabular}{|c|c|c|c|c|c|c|c|c|c|}
\hline \multicolumn{2}{|c|}{$\begin{array}{l}\text { 風 } \mathrm{c} \text { 速 } \\
\mathrm{cm} / \mathrm{se}\end{array}$} & $\begin{array}{c}1.0 \\
\tilde{3.9}\end{array}$ & $\frac{4.0}{6.9}$ & \multicolumn{4}{|c|}{ 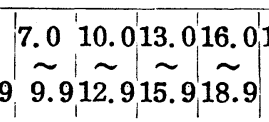 } & $\stackrel{19.0}{\sim}$ & 計 \\
\hline 1 & $\sim$ & 0 & 0 & 0 & 0 & 0 & 0 & 0 & 0 \\
\hline 2 & $\sim$ & 0 & 0 & 0 & 0 & 0 & 0 & 0 & 0 \\
\hline 3 & $\sim$ & 14 & 1 & 0 & 0 & 0 & 0 & 0 & 15 \\
\hline 4 & $\sim$ & 0 & 2 & 1 & 0 & 0 & 0 & 0 & 3 \\
\hline 5 & $\sim$ & 0 & 0 & 0 & 0 & 0 & 1 & 1 & 2 \\
\hline 6 & $\sim$ & 0 & 0 & 0 & 0 & 0 & 0 & 0 & 0 \\
\hline & & 14 & 3 & 1 & 0 & 0 & 1 & 1 & 20 \\
\hline
\end{tabular}

表 2 に示される通り，気流は $4.0 \mathrm{~cm} / \mathrm{sec}$ 未満が最 も多く, 且つ大部分が $6.9 \mathrm{~cm} / \mathrm{sec}$ 以下であつて, 夏期 のそれが 4.0 12.9 cm/sec が多いのと比較して, 冬期 にはより以上風の少いことを望んでいることが知られる であろろ。

乾カタ冷却力については 3.1 5.6 (平均3.8) の範囲 にあり, しかも大部分は夏期同様 $3 \sim$ 代であり, 且つ その 3 〜 代の平均も夏期と同様 3.4 であつた。

\section{III 総括並に考按}

コンジットウエザーマスター式による Air Conditioning の詳細は別に報告されるが，本法の特徵の一つ として, 夫々の室に於て或る程度自由に調節のできるこ とがあげられている。従つて本法に基いて得られた室内 環境 (温度, 湿度, 気流等) は夫々の室居住者の好む如 く調節されたるのとも云い得るであろう。

ところで生体が温度的の作用により寒暑感を覚えるの は前記の如く主として気温, 気湿, 気流及び輻射熱の 4 因子に左右されるるのであり，生体の寒暑感を機械的に 指示し得べき完全な手段は完成されたとは云い得ないの であるが,この温度条件の生物学的単位の1つとしての カタ寒暖計はそその着想として劃期的のものであつた。 前述の通りこのものの価値の評価は現今低下されて来た とはいえ，人体冷却の比率を標示すると共に，方向不定 の不感気流の湘定器として,な搞無視しきれない価値は 残されていると考える。

しかるに Air Conditioning の実態調查に際して, 快 感域にあると思われる個所の乾カタ冷却力を測定し，そ の数值が従来考えられていたるのと比較して多少異つて いるらしいことが知られ，この目的から快感域に於ける 乾カタ冷却力を室内気流と共に検討したのである。
しかるに生体の温度条件に対する反応が個々の物理的 条件の各々に対してではなく, 前記のように気温, 気湿, 気流,輻射熱等の複合したものに対してである以上,いか なるものを快感域とするかについては間題となろうが, 筆者は（それは民族的に改変さるべき疑間は残している が）実用性に於て有利であるとの意見)から感覚温度に 基き，その快感带に含まれる個所を選んだ。しかしてこ の際室内居住者が不快（暑い或は寒い等）を訴えていな い個所であることは云うまでもない。

ところで快適とされる乾カタ冷却力について，2.5 は heiss, 5.0は angenehm warm, 7.5は angenehm kühl とする場合4)，5.0以下を angenehm，4.6以下はwarm, 4.3以下は heiss となす場合 ${ }^{5)}, 4.6 \sim 5.0$ Normalwerte となす場合6)，或は6をるつて坐業者に快適となす場合 7),8) 等, 概ね 5 前後より 6 位の間が坐業者に快適と云い得 ベく, 4.6 以下, 就中 4.3 以下は heiss であつて送風 を要する程度とされているょうである。

しかるに今回の測定に於て快感域にあると認められた 個所の乾力夕冷却力をみるに, 暑熱の候に於てる寒冷の 候に於て子, 何れる大多数が 3 代であり, 且つ共に その平均は 3.4 であつたこと,及び 8 月の調查時の他の 或る個所で, “少し凉しすぎる”と訴兄られていた 2 ケ 所の乾カタ冷却力が夫々 5.1 及び 5.3 であつたこと等よ り，坐業者に快啇とされる乾力夕冷却力は再考を要すべ きであろうことが認められ，坐業者に快適とされる乾力 タ冷却力は従来考えられている数值よりも更に少い数値 でも適当であろうこと, 或は 3 代でも十分快適とさ れ得るであろうことが考えられた。

次に快感域に於ける室内気流に関しては, $30 \mathrm{~cm} / \mathrm{sec}$ 以 下とか ${ }^{9)}, 0.5 \sim 3$ 吹/秒とか10)記載されている程度で, 余 り明かには示されていない上らである。しかし気温, 気 湿が調節される場合, 室内気流をどの程度にすべきかは 当然考慮さるべき点であり、コンジットウエザーマスタ 一式の Air"Conditioning に於ては 7.6 10.2 cm/sec が目標とされていだ11。

ここにも幸いに本法が各室に於て調節が可能であると 云了特徵から, 実際に室居住者がどの位の室内気流を求 めているかが5かがわれるはずである。即ち表 1,2 の 成樍にみる如く, 夏期では大体本法に上る室内気流の目 標に近い 7 から $10 \mathrm{~cm} / \mathrm{sec}$ 末满の風速を示す場合が多 く, 大部分が 4 から $13 \mathrm{~cm} / \mathrm{sec}$ 末满であつたのに反し, 冬期化は $4 \mathrm{~cm} / \mathrm{sec}$ 末満が多く, 大多数が $7 \mathrm{~cm} / \mathrm{sec}$ 末 满と云了ように, 可及的気流の少いことが求められてい るらしいことが知られる。しかも8月の測定に際して 
某 2 万所で 43.4 及び $54.5 \mathrm{~cm} / \mathrm{sec}$ の風速ではむしう 不快が訴えられていたこと等, 室内気流は夏期でも 4 か $513 \mathrm{~cm} / \mathrm{sec}$ 未満で十分であつて, 20 乃至 $30 \mathrm{~cm} / \mathrm{sec}$ 以 上は要しないであろうし，これ仅して冬期では可及的 風速の少い上弓，少くとも $7 \mathrm{~cm} / \mathrm{sec}$ 未满が求められ ていると云われるであるう。

\section{IV 結 語}

Air Conditioning を行つている2 新築ビルに於て快 感域にあると認められる個所の乾カタ冷却力と室内気流 とを検討し, 乾カタ冷却力は暑熱の 8 月る寒冷の 1 月る 共に 3 代 (平均は何れも3.4) が最も多く, 室内坐業 者に快適とされ得る乾力夕冷却力は従来云われている数 值 (5 6 前後) 上り更に少くても快適であり得るである らこと, 或は 3.0 3.9 の範囲でも十分適当であると云 い得べきこと, 更に室内気流については夏期でも 4 から $13 \mathrm{~cm} / \mathrm{sec}$ 末満で十分であり，20〜30 cm/sec 以上の 風速は必ずしも要しないこと, しかして冬期では夏期に 比して更に風速は少く, $7 \mathrm{~cm} / \mathrm{sec}$ 未满で足りること等 が認められた。

本交の要旨は昭和28年 5 月, 日本衛生学会総会に於て
口演発表した。

終りに御校閲を戴いた萩原兼交教授，穴戸昌夫助教授 に深謝すると共に, 種々御便宜, 御協力を得た東洋キ+ リア工業株式会社平野彥兵衞氏始め関係職員各位に謝意 を表したい。

\section{文献}

1) 石川知福：環境衛生学, 14, 東京, 1948

2) 同上: 33頁

3) 井上善十郎：新衛生学, 65, 東京, 1951

4) H. Reichenbach:E.v. Esmarch's Hygienische Taschenbuch, 21, Berlin, 1930

5) Reiner Müller : Lehrbuch der Hygiene für Ärzte und Biologen, 6, München, 1935

6) Werner Kollath : Grundlagen Methoden und Ziele der Hygiene, 174, Leipzig, 1937

7) 鯉沼荡吾 : 衛生学, 32, 東京, 1948

8) 原島進 : 環境衛生学, 36, 東京, 1950

9) 庄司光 : 住居の衛生学, 85, 京都, 1947

10） 8）と同書の 14 頁

11）東洋キャリア工業株式会社提供資料より 